\title{
Population size, habitat association and dietary composition of Boutourlini's blue monkeys (Cercopithecus mitis boutourlinii) in Komto Protected Forest, Western Ethiopia
}

\author{
Mosissa Geleta $^{1,2 \star}$ and Afework Bekele ${ }^{2}$ \\ ${ }^{1}$ Department of Biology, Wollega University, P.O. Box 395, Nekemte, Ethiopia. \\ ${ }^{2}$ Department of Zoological Sciences, Addis Ababa University, P. O. Box 1176, Addis Ababa, Ethiopia.
}

Received 24 June, 2016; Accepted 5 August, 2016

\begin{abstract}
A study on the population size, habitat association and dietary composition of Boutourlini's blue monkeys (Cercopithecus mitis boutourlinii) was carried out from January, 2015 to September, 2016 in Komto Protected Forest. Data was collected for a total of 58 days encompassing both the wet and dry seasons. Scan sampling method was used to collect data on the diet and foraging behaviour of Boutourlini's blue monkeys. Population size was determined by total counting method. A total of two groups (natural and riverine forest) and 29 individuals of Boutourlini's blue monkeys were recorded in the study area. Natural forest group was selected to study about the diet and foraging behaviour of Boutourlini's blue monkeys. The overall dietary composition of Boutourlini's blue monkeys was dominated by young leaves which accounted for $27.40 \%$ of the total diet. In addition, they fed on mature leaves $(20.3 \%)$, fruits $(15.38 \%)$, flowers $(11.24 \%)$, shoots $(8.99 \%)$, bark $(6.91 \%)$, seeds $(4.93 \%)$ and animal matter (3.37\%). They consumed a total of 21 plant species belonging to 18 families. Syzygium guineense was the most consumed plant species and constituted $16.68 \%$ of Boutourlini's blue monkey diet followed by Ficus sur (13.13\%) and Prunus africana (12.01\%). The most often utilized foraging method was capturing and manipulating food using both hands. This accounted for $47.97 \%$ of total foraging observations followed by grabbing (31.46\%) and pulling $(11.93 \%)$. Boutourlini's blue monkeys were restricted to natural and riverine forest habitats in Komto Protected Forest. Preference of such taper ecological niche resulted from selective deforestation for timber and charcoal production, trampling of habitats by livestock and agricultural land expansion. To ensure future conservation of Boutourlini's blue monkeys, habitat rehabilitation, enforcement of laws against deforestation for timber and charcoal production, and other appropriate management and conservation strategies should be designed.
\end{abstract}

Key words: Boutourlini's blue monkeys, diet, foraging behavior, habitat association, Komto Protected Forest.

\section{INTRODUCTION}

Blue monkeys (Cercopithecus mitis) are forest dwelling guenons belonging to the Old World monkeys (Kingdon,
1971; Estes, 1992). There are 17 subspecies of blue monkeys spreading in different habitat types and forests 
of south, east and Central Africa (Wolfheim, 1982). As a species, the conservation status of Blue monkeys is "least concern" with a decreasing population trend (Kingdon et al., 2008). Blue monkeys are mostly adapted to live in the forests and forage at $20 \mathrm{~m}$ above the ground (Tashiro, 2006). However, they intermittently move in open habitats and feed on the ground (Stuart, 1997). They are adapted in varieties of habitats such as rain forests, coastal mangrove forests, forest patches in savannah and evergreen semi-deciduous forests (Kingdon, 1971; Estes, 1992). The diets of blue monkeys are mostly flexible (Kingdon, 1971; Chapman et al., 2002; Twinomugisha et al., 2006). The flexibility of diet is associated with their large hindgut specialization to various types of food (Twinomugisha et al., 2006). Fruits were the most frequently used plant components though high amounts of leaves and invertebrates were consumed periodically (Cords, 2002). As an omnivore, blue monkeys mostly feed on fruits, leaves, invertebrates, flowers, seeds, bark and shoots (Estes, 1992).

Blue monkeys are frugivoure primates which are sensitive to the removal of forest as it reduces the availability of food (Cordeiro et al., 2004). Habitat loss due to commercial timber, agriculture and others means of human resource gathering threatens forest specialist primates (Chapman et al., 2006). Remnant forest patches are surrounded by encroachments, overgrazing and agricultural lands. This has caused a number of changes such as reduction of mammal populations, altered diets and foraging behaviours (Mbora and Meikle, 2004). Plant species composition and diversity is low in fragmented and disturbed forests. This in turn affects the availability of food for the species (Wong and Sicotte, 2006). Food supply is an important determinant factor that limits population abundance (Rode et al., 2006; Rovero and Struhsaker, 2007). Loss of food may increase competition between species. It is also the cause for aggressive interactions among animals thereby increasing stress and reduction of reproduction. Consequently, such habitat loss and fragmented habitats leads to local extinction of species (Mbora and McPeek, 2009). Most primates are forest specialists and thus vulnerable to habitat fragmentation (Chapman et al., 2007). As revealed by IUCN (2010), nearly half of the species are threatened with extinction due to habitat destruction and hunting. Most primate species and subspecies are threatened due to habitat loss and degradation in tropical regions (Cowlishaw, 1999; Chapman and Peres, 2001; Kerr and Deguise, 2004). To conserve such threatened species, information on the population size, diet selection and foraging behaviour of species is very important (Sutherland, 1998). Blue monkeys as a species are not threatened (Lawes, 1990).
However, the subspecies are highly localized and information on their basic biology, ecology and conservation is very limited (Oates, 1996; Kingdon et al., 2008). Boutourlini's blue monkeys (Cercopithecus mitis boutourlinii), is a forgotten subspecies endemic to the Southwestern Ethiopian Rift Valley between Lake Tana and Lake Turkana (Yalden et al., 1977; Butynski and Gippoliti, 2008). They had never been the subject of study, and thus their biology, ecology and social behaviour is unknown (Tesfaye et al., 2013). They are listed as Vulnerable by IUCN because of the severe destruction and fragmentation of forests (Butynski and Gippoliti, 2008). Currently, this subspecies is widely distributed in protected areas and remnant forest patches of the southwestern parts of Ethiopia. Studies on ecology, biology and behavioural patterns of Boutourlini's blue monkey are lacking. To ensure the efficiency of future conservation of Boutourlini's blue monkeys, it is important to study the ecology, biology and behaviour of this subspecies. The study of foraging behaviour is important to understand the adaptation of a species to its environment. The study of diet in particular can help to know population dynamics, habitat use and social organization of the species (Maruhashi, 1980). The present study, therefore, aimed to investigate the population size, habitat association and dietary composition of Boutourlini's blue monkey in Komto Protected Forest.

\section{MATERIALS AND METHODS}

\section{Study area}

Komto Protected Forest is located in Western Ethiopia in Oromia Regional State of East Wollega Administrative Zone. It is situated between $9^{\circ} 05^{\prime} 10^{\prime \prime}$ to $9^{\circ} 06^{\prime} 35^{\prime \prime} \mathrm{N}$ latitude and $036^{\circ} 36^{\prime} 47^{\prime \prime}$ to $036^{\circ}$ $38^{\prime} 10^{\prime \prime}$ E longitude with an elevation ranging from 2,135 to 2,482 m asl (Mosissa et al., 2011). Komto Protected Forest is part of the National Forest Priority Area called Komto Wacha Tsige Protected Forest which is currently fragmented from the other parts of the forest by increased expansion of agricultural lands, overgrazing, encroachments and commercial harvesting of both natural and plantation forests. Currently, it has a total area of 1888.09 ha including both disturbed and undisturbed habitats (Figure 1). The study area falls within the southwestern and western unimodal rainfall region of Ethiopia with little or no rainfall in December, January and February. Rainfall gradually increases to peak from June to September. The mean annual rainfall of the area for 2002 to 2011 was $2143 \mathrm{~mm}$. The mean minimal temperature was $12.1^{\circ} \mathrm{C}$ and the mean maximum was $28.1^{\circ} \mathrm{C}$.

\section{Description of habitats types}

Komto Protected Forest is characterized by moist evergreen afromontane forest in which trees form an open canopy. The 


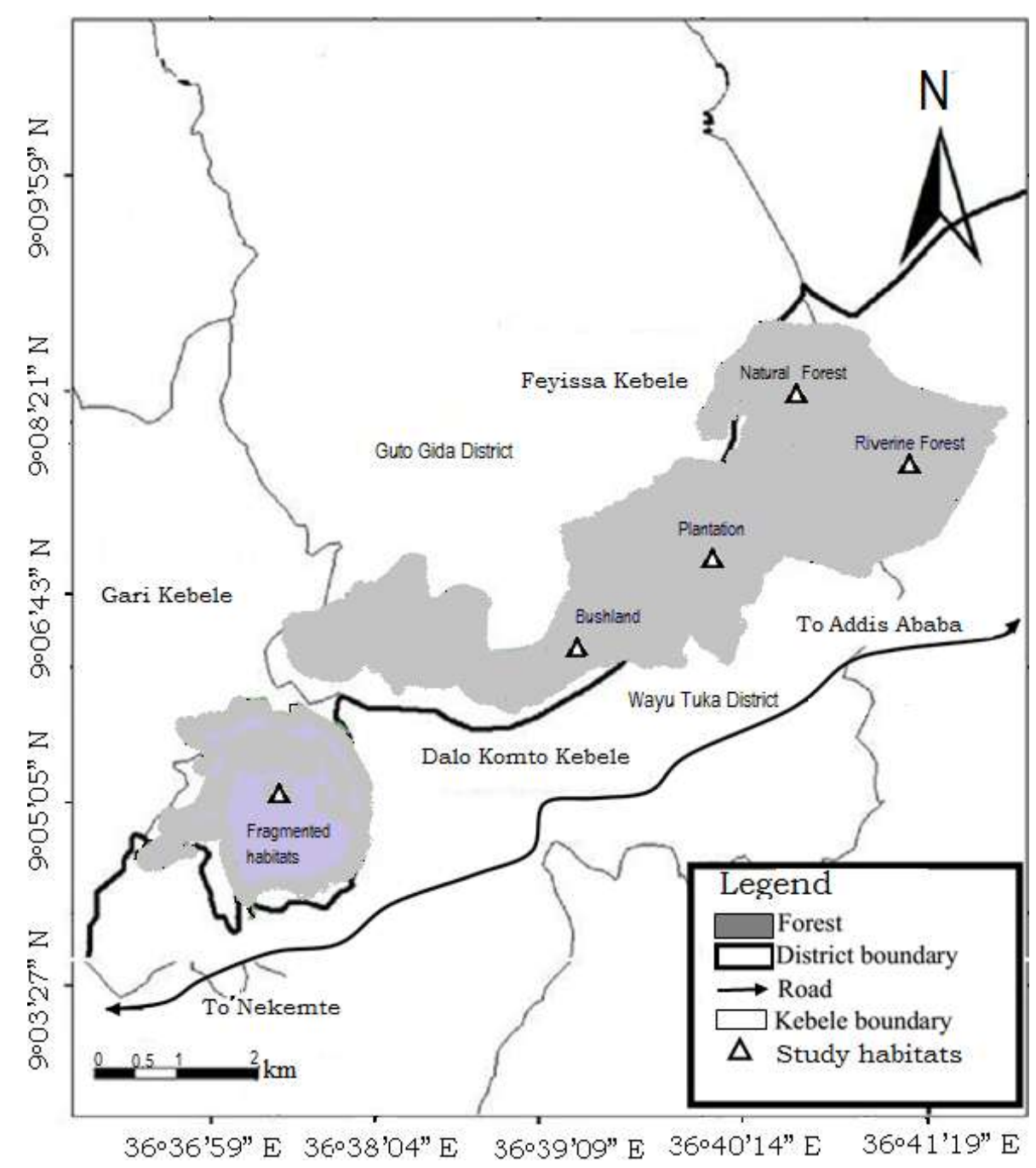

Figure 1. Map of Komto protected forest.

vegetation type of the study area consists mainly of natural and man-made forests. Komto Protected Forest consists of about 180 plant species belonging to 28 genera and 21 families. The forest contains about 18 plant species endemic to Ethiopia. Of all families, Fabaceae and Asteraceae dominant followed by Lamiaceae, Malvaceae and Poaceae (Fekadu et al., 2013). The species composition of plantation forest includes Eucalyptus spp., Cupressus lusitanica, Grevillea robusta and Pinus radiata. The study area was stratified into five habitat categories based on the vegetation types, structure and conservation status of the forest. These include: Natural forest, riverine forest, bushland, plantation and fragmented habitats.

\section{Data collection}

Due to low density of Boutourlini's blue monkeys in the area, total counting method was used to determine their population size (Norton-Griffiths, 1978). The open nature and fragmentation of the forest made total counting Boutourlini's blue monkey easier. Five habitat categories were identified (natural forest, riverine forest, plantation, fragmented habitats and bushland) to assess Boutourlini's blue monkeys in the area. To ensure total counts, four individuals living adjacent to the forest were trained and assigned to each habitat type to simultaneously assess the locations of Boutourlini's blue monkey both during the dry and wet seasons. Assessment was conducted from 07:00 to 11:00 in the morning and 14:00 to 17:30 p.m. in the afternoon. The presence of Boutourlini's blue monkeys were detected only in natural and riverine forests. Detected troops were named as natural forest group (NF Group) and riverine forest group (RF Group). To minimize underestimation of population size, five transect lines were additionally used in the surrounding remnant forest patches. However, no Boutourlini's blue monkey troops were detected in the surrounding areas during both seasons. Accordingly, counting of Boutourlini's blue monkeys was carried out in the two habitats. During counting, individuals located at distances of between 20 and $30 \mathrm{~m}$ from one another were considered as one group. To study the foraging behaviour of Boutourlini's blue monkeys, the natural forest group was selected for detailed study. The group was selected because they are easily accessed compared to the riverine forest group. The riverine group was excluded due to inconveniences of steep slope of the area to follow the group. The groups were identified by their habitat types and total number of individuals that made the troop. In addition, the groups were about $300 \mathrm{~m}$ part from each other.

Dietary data were collected for 58 days covering both the dry 
Table 1. Population size of Boutourlini's blue monkeys in Komto protected forest.

\begin{tabular}{lclcccc}
\hline & Total size & Sex & Adults & Sub-adults & Juveniles & Infants \\
\hline \multirow{3}{*}{ NF } & \multirow{2}{*}{17} & Male & 2 & 3 & 2 & - \\
& & Female & 6 & 2 & - & - \\
& & Unknown & - & - & - & 2 \\
\multirow{3}{*}{ RF } & Male & 1 & 2 & 1 & \\
& \multirow{2}{*}{12} & Female & 4 & 2 & - & \\
\hline
\end{tabular}

$\mathrm{NF}$, Natural forest; RF, Riverine forest.

(January-March, 2015) and wet (July-September, 2015) seasons. Scan sampling method (Altmann, 1974) was used to collect data on the foraging behaviour of multiple group members. Scan sampling was conducted at 15 min intervals between 07:00 a.m. and 11:00 with an observation period lasting for $5 \mathrm{~min}$. Observation of all visible adults and sub-adults in the focal groups were carried out early in the mooring starting from their roosting sites until they disappeared from sight. Scanning was carried out interchangeably from left to right for the first scan and then from right to left for the second to minimize the risk of recording the same animal twice or being biased by recording the most obvious animals (Abernethy, 2000). Close habituation to the focal group was not successful as humans had chased them during illegal logging over longer periods. Due to this, the troop was partially habituated and scan sampling was conducted using unaided eyes and or binoculars from a distance of approximately 30 to $40 \mathrm{~m}$ during the wet and dry seasons, respectively.

Foraging is defined as ingesting food items, manipulating (with the hands or mouth), carrying (in the mouth) and searching for food items using visual scanning in combination with grasping or searching with arms (Bunce et al., 2011). Food capturing techniques of monkeys were mainly classified as grabbing (quickly and easily capturing the prey or food with one hand), catching (grasping and or holding food with two hands and eating), pulling (exerting strong force to cause movement of food towards itself) and mouth grabbing (removing food items with mouth alone) (Baum, 2005; Nekaris, 2005). Monkeys used these methods of food extraction depending on the distance, types and strength of branches where food items were located (Baum, 2005). Capturing as food acquisition techniques was mostly used when the monkeys have appropriate sit at the middle of tree branches whereas grabbing was used when they are found closer to the terminal branches. Grabbing with mouth was used as food acquisition techniques when monkeys sat in many branches with thick foliages. However, pulling was mostly used when they feed attempts to feed on strong and unreached tree branches. Therefore, during scan sampling, mechanisms of food extractions (grabbing, catching, pulling and mouth grabbing) were recorded only from the adults and sub-adults assuming that juveniles and infants often learn from adults and sub-adults (Baum, 2005). In addition, food items and types of plant species consumed were recorded. Food items were recorded as young leaves, mature leaves, flowers, fruits, seeds, shoots, barks and unknown (when unknown plant parts or animal matters were consumed) (Fairgrieve and Muhumuza, 2003; Di Fiore, 2004). Identification of most plant species in the forest was easier as the species composition of the forest was studied (Fekadu et al., 2013). However, unidentified plant species, during the study periods, were collected and identified by an expert. Consumption of animal matters were recorded when a monkey was observed scratching tree barks and searching, and exposing curled leaves or ingesting invertebrates (Dietz et al., 1997).

\section{Data analysis}

Diet composition was evaluated by calculating the proportion of different food items and species consumed by the monkeys. The daily food items and type of species consumed by the groups was summed to calculate seasonal proportion of food items and food types consumed (Abernethy, 2000). The relative proportion of plant species used as food was calculated from the seasonal percentage contribution of different species (Fashing, 2001; Di Fiore, 2004). To get the percentage of food item foraged from each plant species, each foraged plant species and food item was summed per species. And, the percentage of each food item was calculated related to all food items per individual plant species. To determine the percentage utilization of a species, the total number of sightings of feeding on a forage species was divided by the total number of sightings for all species eaten (Abernethy, 2000). The total number of observations and frequencies were calculated for food extraction methods. Chi-Square analyses were used with SPSS V17.0 with probability set at the 0.05 level of significance.

\section{RESULTS}

A total of two groups and 29 Boutourlini's blue monkeys were recorded in Komto Protected Forest (Table 1). Among these 17 individuals were recorded in natural forest and the remaining 12 were recorded in the riverine forest. The difference in the number of individuals observed between the two habitats was not significant $\left(x^{2}=0.18, \mathrm{df}=1, P>005\right)$. From a total of 29 Boutourlini's blue monkeys recorded in the area, females and males constituted about 48.28 and $37.93 \%$, respectively. Adult females comprised $(41.38 \%)$ followed by sub-adult males which accounted for $17.24 \%$ of the total population. Adult males and infants of unknown sex comprised 10.34 and $13.79 \%$, respectively.

The comparative use of different habitat types by Boutourlini's blue monkeys in Komto Protected Forest was indicated by the number of individuals observed in each habitat type. Natural forest was utilized both during the dry $(60 \%)$ and wet $(58.62 \%)$ seasons. Riverine forest was the second habitat type utilized during both seasons. However, Boutourlini's blue monkeys did not use bushland, plantation and fragmented habitats. The variation in the number of Boutourlini's blue monkeys observed in different habitats types was significant 


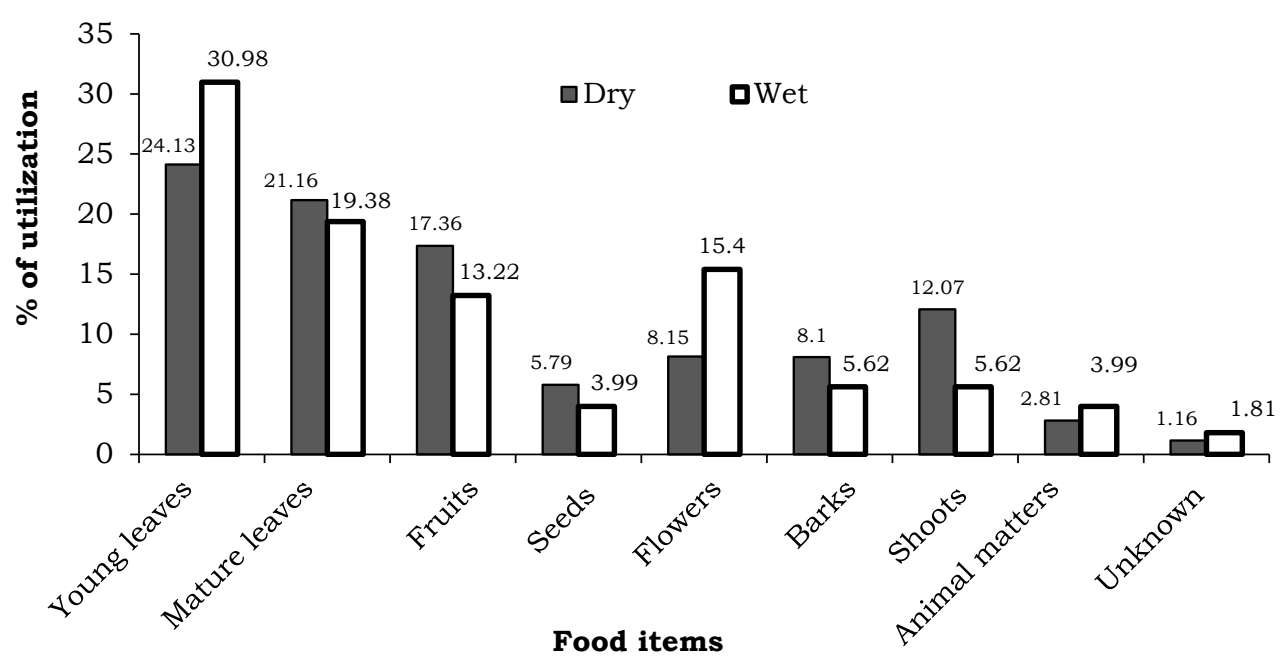

Figure 2. Percentage of food consumed by Boutourlini's blue monkeys during the wet and dry seasons.

$\left(x^{2}=82.86, \mathrm{df}=4, \mathrm{P}<0.05\right)$.

A total of 1157 feeding observations were recorded from a total of 2320 scan samples carried out during the two seasons. A total of 21 plant species, animal matters and unknown food items were consumed by Boutourlini's blue monkeys. The majority of feeding were recorded for young leaves $(27.40 \%)$ followed by matured leaves $(20.30 \%)$ and fruits $(15.38 \%)$. About $3.37 \%$ of the total consumed food constituted by animal matters. Some food items were recorded as unknown (1.47\%) as consumed items were not easily recognized. Feeding recorded for the male and female individuals accounted for $55.22 \%$ $(\mathrm{N}=639)$ and $44.77 \%(\mathrm{~N}=518)$, respectively. The total feeding recorded for Boutourlini's blue monkey during the dry season ( $\mathrm{N}=605)$ 49.96\% was slightly greater than the wet season ( $\mathrm{N}=552) 49.35 \%$. But there is no significant variation in the number of feeding observation recorded between seasons $\left(x^{2=0.15,} \mathrm{df}=1, \quad P>0.05\right)$ but the difference was significant between males and females $\left(X^{2=12.65}, \mathrm{df}=1, \mathrm{P}<0.05\right)$.

Among plant parts consumed as food, the percentage of feeding on matured leaves $(21.16 \%)$, fruits $(17.36 \%)$, seeds $(5.79 \%)$, barks $(8.10 \%)$ and shoots $(12.07 \%)$ were higher during the dry than the wet season, 19.38, 13.22, $3.99,5.62$ and $5.62 \%$, respectively. However, the percentages of feeding recorded for young leaves $(24.13 \%)$ and flowers $8.15 \%$ were low during the dry season but increased to 30.98 and $15.40 \%$ during the wet season, respectively (Figure 2). Feeding recorded for animal matters are also slightly greater during the wet season (3.99\%) than the dry season $(2.81 \%)$. Stems and roots were not observed being consumed during any of the feedings. There was no significant difference in the utilization of young leaves $\left(X^{2=1.97,} \mathrm{df}=1, \quad P>0.05\right)$,

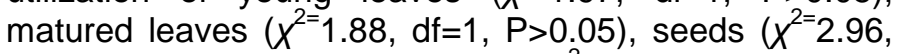
$\mathrm{df}=1, \mathrm{P}>0.05)$ and animal matters $\left(X^{2=0.64, \mathrm{df}=1, P>0.05)}\right.$ between seasons. However, the utilization of bark $\left(x^{2=} 4.05, \mathrm{df}=1, \mathrm{P}<0.05\right)$, shoots $\left(x^{2=} 16.96, \mathrm{df}=1, \mathrm{P}<0.05\right)$,

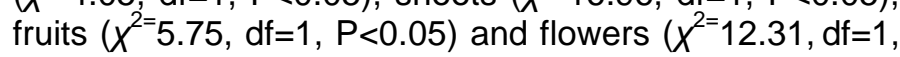
$\mathrm{P}<0.05)$ showed significant difference between seasons.

Boutourlini's blue monkeys consumed a total of 21 plant species belonging to 18 families. Among the total consumed species, $61.90 \%$ belong to trees and the remaining species were shrubs $(19.05 \%)$, climbers $(9.52 \%)$ and epiphytes $(4.76 \%)$. Boutourlini's blue monkey mostly relied on young leaves, mature leaves and fruits. Young leaves were the principal food item consumed by this species. Family Rosaceae contributed 4 species for the diet whereas the remaining families were represented by one species each (Table 2).

The top ten most consumed plant species accounted for $79.85 \%$ of the overall diet of Boutourlini's blue monkeys (Figure 3). Syzygium guineense was the most consumed plant species which accounted for $16.68 \%$ of their diet followed by Ficus sur (13.13\%) and Prunus africana $(12.01 \%)$. Among the top ten species, six of them belong to trees. The remaining three and one species belong to shrubs and climbers, respectively. The most utilized shrub species accounted for $30 \%$ of top ten consumed plant species.

Among different types of foraging behaviour of Boutourlini's blue monkeys, the most utilized method was capturing and manipulating food with the aid of two hands. This method exhibited $47.97 \%$ of total feedings records $(\mathrm{N}=555)$ out of which males accounted for 50.23 $\%(\mathrm{~N}=321)$ and females $45.17 \%(\mathrm{~N}=234)$. Grabbing foods $31.46 \%(\mathrm{~N}=364)$ and acquiring food by pulling accounted for $11.93 \%(\mathrm{~N}=138)$ which were the second and third food acquisition techniques, respectively. There was significant difference between the four types of food acquisition techniques by Boutourlini's blue monkeys $\left(x^{2}=387.57, \mathrm{df}=3, \quad \mathrm{P}<0.05\right)$. However, there was no 
Table 2. Plant species and parts consumed by Boutourlini's blue monkeys in Komto protected forest.

\begin{tabular}{|c|c|c|c|c|c|c|}
\hline Habit & Family & Plant species & Parts eaten & Feeding record & $\%$ of utilization & Local name \\
\hline Tree & Myrtaceae & Syzygium guineense & $\mathrm{YL}, \mathrm{ML}, \mathrm{FR}$ & 193 & 16.68 & Baddeessaa \\
\hline Tree & Moraceae & Ficus sur & $\mathrm{BA}, \mathrm{FR}, \mathrm{YL}$ & 175 & 13.13 & Harbuu \\
\hline Tree & Rosaceae & Prunus africana & $\mathrm{SH}, \mathrm{BA}, \mathrm{FR}$ & 139 & 12.01 & Goraa \\
\hline Tree & Meliaceae & Ekebergia capensis & $\mathrm{SH}, \mathrm{YL}, \mathrm{BR}, \mathrm{FR}$ & 103 & 8.90 & Hoomii \\
\hline Tree & Myrsinaceae & Embelia schimperi & YL, ML,FR & 102 & 8.82 & Haanquu \\
\hline Shrub & Rosaceae & Rubus apetalus & $\mathrm{FL}, \mathrm{FR}$ & 60 & 5.19 & Goraa arbaa \\
\hline Shrub & Rosaceae & Rubus steudneri & $\mathrm{FL}, \mathrm{FR}$ & 52 & 4.49 & Waddeessa \\
\hline Tree & Boraginaceae & Cordial africana & $\mathrm{FR}, \mathrm{SE}$ & 47 & 4.06 & Somboo \\
\hline Shrub & Rosaceae & Rosa abyssinica & SE, FR & 41 & 3.54 & Qagaa \\
\hline Climber & Urticaceae & Urera hypselodendron & $\mathrm{SH}, \mathrm{FL}$ & 35 & 3.03 & Laanqessaa \\
\hline Tree & Rubiaceae & Rytigymia neglecta & YL, ML & 31 & 2.68 & Mixoo \\
\hline Climber & Ranunculaceae & Clematis hirsute & $\mathrm{YL}$ & 26 & 2.25 & Hidda fiitii \\
\hline Tree & Rutaceae & Vepris dainellii & FR & 23 & 1.99 & Hadheessa \\
\hline Tree & Fabaceae & Albizia gummifera & SE & 19 & 1.64 & Mukarbaa \\
\hline Tree & Apocynaceae & Carissa spinarum & SE, FR & 15 & 1.30 & Agamsa \\
\hline Tree & Flacourtiaceae & Dovyalis abyssinica & YL,FR & 13 & 1.12 & Koshimii \\
\hline Tree & Dracaenaceae & Dracaena steudneri & $\mathrm{FR}$ & 10 & 0.86 & Warqe Qamalee \\
\hline Tree & Euphorbiaceae & Croton macrostachyus & $\mathrm{BA}, \mathrm{SE}$ & 7 & 0.61 & Bakkanisa \\
\hline Shrub & Crasulaceae & Kalanchoe densiflora & $\mathrm{YL}, \mathrm{SH}$ & 5 & 0.43 & Bosoqqee \\
\hline Shrub & Tliaceae & Triumfetta rhomboidea & $\mathrm{FR}$ & 3 & 0.26 & Hincinnii \\
\hline Epiphytes & Loranthaceae & $\begin{array}{l}\text { Phragamanthera } \\
\text { macrosolen }\end{array}$ & $\mathrm{SH}$ & 2 & 0.17 & Dheertuu \\
\hline
\end{tabular}

FL, Flowers; FR, fruit; ML, mature leaves; SE, seeds; YL, young leaves; SH, shoots; BA, barks.

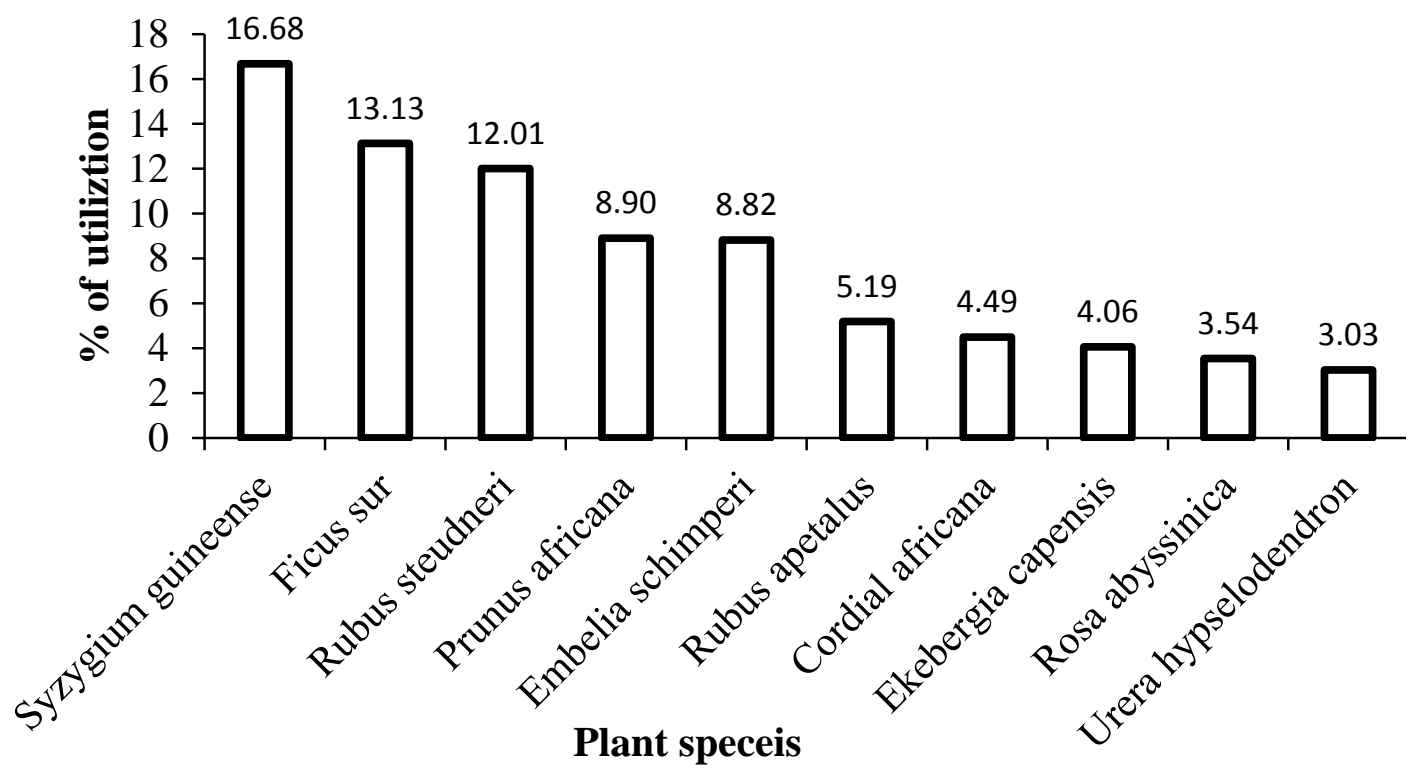

Figure 3. Top ten plant species utilized by Boutourlini's blue monkeys in Komto Protected Forest.

significant difference in grabbing $\left(X^{2}=7.43, \mathrm{df}=3, \mathrm{P}>0.05\right)$, pulling $\left(x^{2}=4.17, \mathrm{df}=3, \quad \mathrm{P}>0.05\right)$ and mouth grabbing $\left(X^{2}=0.36, \quad d f=3, P>0.05\right)$ as food acquisition methods between male and females. Catching as food acquisition method varied significantly between males and females $\left(x^{2}=13.64, \mathrm{df}=3, P<0.05\right)$. 


\section{DISCUSSION}

The remnant forest patches around mountainous and riverine forests of Western Ethiopia serve as a good refuge for Boutourlini's blue monkeys. However, the biology, ecology and behaviour of this subspecies have not been studied (Tesfay et al., 2013). Hence, the findings of this study are mostly compared with other guenons and similar subspecies studied in other African countries. Boutourlini's blue monkeys were recorded only in the natural and riverine forests of Komto Protected Forest. As described by Leighton (1993), they prefer matured forest due to the existence of sufficient fruit and structural features that assists arboreal movement. The number of Boutourlini's blue monkeys recorded increased from 15 to 17 in the natural forest and from 10 to 12 in the riverine forest. This increment was attributed to birth during the wet season. Similar finding was reported from Jibat Forest, Ethiopia by Tesfaye et al. (2013). The population size of Boutourlini's blue monkey recorded during the present study was very low which might be attributed to anthropogenic activities that resulted in reduction of food sources in the area. As reveled by Kempe (2008), frugivorous primates are shown to be very sensitive to forest clearings as it may reduce the population due to scarcity of food. According to Chapman and Chapman (2002) and Wallace et al. (1998), the abundance and density of primates were related to food quality and availability. Similarly, continuing decline in the number of blue monkey has been observed in the Kibale National Park, Uganda due to large timber cuttings (Chapman et al., 2000). Blue monkey was unable to cope with the increasing rate of deforestation and habitat fragmentation in Africa (Lawes and Chapman, 2003).

Though blue monkey are adapted to live in varieties of forest habitats (Kingdon, 1971; Estes, 1992), they are occasionally observed foraging on the ground across open habitats (Stuart, 1997). However, they reject bushland, fragmented habitats and plantation forests in Komto Protected Forest. This might be linked with the severe disturbance, poor shelter and scarce food in these habitats. In addition, Boutourlini's blue monkey might avoid open habitats due to attacks of predators as witnessed by Jaffe and Isbell (2007). Blue monkey can be found in forest fragments if and only if they are survival groups originating from periods with larger forests rather than newly immigrated animals (Kempe, 2008).

The diet of blue monkeys comprises a few plant species (Fairgrieve and Muhumuza, 2003). This is also the case during the present study in which most food items were consumed from a few plant species. Among the 21 plant species consumed by Boutourlini's Blue monkeys, the top ten consumed plant species accounted for $79.85 \%$ of their overall diet. This might be linked to the preference of larger trees for sheltering and predator avoidance as humans frequently visit the forest for timber production. Syzygium guineense is the most foraged plant species in the study area. This is because the tree possesses dense and evergreen foliage throughout the year with more foliage observed during the dry season. Ficus sur is the second most preferred plant species in the study area. Similarly, C. $m$. stuhlmanni utilized Ficus species in Masai Mara National Reserve in Kenya (Kempe, 2008). To the contrary, feeding on shrubs, herbs and climbers was insignificant because the area was under high human pressure due to various anthropogenic activities. In addition, such plant species are closer to the ground, and might expose them to predation. As stated by Kempe (2008), large trees were used by monkeys both for foraging and positioning high above the ground to protect potential predators.

The sources of food for guenons are as diverse as their habitats though they are selective feeders (Cords, 1986; Kaplin and Moermond, 2000). Blue monkeys are mainly frugivours but also eat leaves, flowers and insects based on availability (Cords, 2002; Fairgrieve and Muhumuza, 2003). However, Boutourlini's blue monkeys mostly utilize young leaves, mature leaves and fruits in Komto Protected Forest. Young and matured leaves have low cellulose and secondary toxic compounds that makes digestion easier (Cords, 1987). In addition, young and matured leaves provide a high percentage of crude protein and calcium, respectively (Rudran, 1978). Blue monkeys at Komto Protected Forest use young leaves, matured leaves and flowers more as food compared to other Cercopithecus spp. (Table 3). However, the amount of feeding recorded for fruits was less among the genus Cercopithecus. The reduction of fruits in the diet of Boutourlini's blue monkeys might be attributed to the shortage of fruits in the forest. In addition, the availability of leaves might be better than fruits in the study area. As stated by Kempe (2008), when fruits are less available in the habitat, they switch to feed on foliar foods. In addition, the foliar diets of frugivours monkeys is an indicator of adaptive lifestyle and periodic fluctuations of food resources.

Dietary flexibility can be resulted from habitat variation, relative abundance of food and food preference of blue monkeys (Rudran, 1978; Chapman et al., 2002). Boutourlini's blue monkey also consumed considerable amounts of fruits, seeds and flowers. Flowers were consumed more during the wet season. This might be linked to the increased production of flowers along within the rainy season. Flowers are generally high in sugar content, providing energy (Wasserman and Chapman, 2003). Seeds and fruits were consumed more during the dry season because flowers produced during the wet season produce fruits and seeds during the dry season. The three food items were seasonal and not available throughout the year. To the contrary, bark, shoots, mature leaves and animal matters were consumed more during the dry season than the wet season. As described by Linderoth (2008), the consumption of more bark during 
Table 3. Percent of feeding records on different food items by members of the genus Cercopithecus in Africa.

\begin{tabular}{|c|c|c|c|c|c|c|c|c|c|c|c|}
\hline Species & $\mathrm{YL}$ & ML & TL & FL & SH & FR & $\mathrm{Am}$ & SD & BA & Country and site & Reference \\
\hline C. mitis boutourlinii & 27.4 & 20.3 & 47.7 & 11.24 & 8.99 & 15.4 & 3.4 & 4.93 & 6.9 & Komto Protected Forest, Ethiopia & This study \\
\hline C. m. boutourlinii & 14.4 & 3.9 & 18.3 & 7.0 & 20.6 & 32.4 & 13.8 & 5.7 & 1.6 & Jibat Forest, Ethiopia & Tesfaye et al. (2013) \\
\hline C. m. doggetti & - & - & 6.2 & 6.2 & - & 47.4 & 24.9 & 9.3 & - & Rwanda & Kaplin (2001) \\
\hline C. ascanius & - & - & 34.7 & 2.7 & - & 44.6 & 17.6 & - & - & Kibale at Sebatoli, Uganda & Chapman et al. (2002) \\
\hline C. ascanius & - & - & 28.8 & 3.7 & - & 35.7 & 31.2 & - & - & Kibale at Kanyawara, Uganda & Chapman et al. (2002) \\
\hline C. nictitans & 10.0 & 0.1 & 10.1 & 4.1 & - & 35.5 & - & 50.2 & - & Gabon & Brugiere et al. (2002) \\
\hline C. hoesti & - & - & 35.2 & 4.0 & - & 24.5 & 8.8 & 17.8 & - & Nyungwe Forest Reserve, Rwanda & Kaplin (2001) \\
\hline
\end{tabular}

YL, Young leaves; ML, mature leaves; TL, total leaves; FL, flowers; SH, shoots; FR, fruit; Am, animal matter; SD, seeds; BA, bark.

the dry season might be attributed to shortage of food. Shoots were utilized more during the dry season because of the low availability of foliage forcing them to feed on shoots. Matured leaves were also consumed more during the dry season though they are less palatable and assumed to have high secondary compounds (Rudran, 1978). This might be an adaptation of Boutourlini's blue monkeys to compensate for food and foliage shortage encountered during the dry season. As stated by Smith (1959), the use of a wide variety of food items is very important to maximize total food consumption. Animal matters such as insects and other invertebrates were used more during the wet season than the dry season. This might be due to the increased number of invertebrates and insects during the wet season. During the present study, males engaged in feeding slightly more than females on average. This might be due to the periodic exclusion of males from the group to live solitarily which decreases time wasted in socialization but increases time of feeding.

Young and matured leaves were utilized more than fruits which coincide with the diets of guenon monkeys being highly flexible, depending upon various conditions (Chapman et al., 2002; Fairgrieve and Muhumuza, 2003). Monkeys used different foraging strategies when feeding on plant parts or animal matters. Among the different methods of acquiring food, preference was shown by Boutourlini's blue monkeys to grasp and or holding food with two hands and then chewing. This accounted for $47.97 \%$ of the total feeding observation. The method might be used by the monkey to easily manipulate food items from branches. Catching method was used more by males than females because the hands of females are busy in handling young. The results of this study suggested that the forearms of females are relatively busy in handling infants, grooming and juvenile feedings. Grabbing was used when the food items are easier and closer to handle with one hand alone. Pulling as a foraging method is used when food items are difficult to reach, and need to pull branches holding food items towards them. Mouth grabbing is used as food acquisition technique when monkeys are positioning in branches having dense foliages closer to the mouth.

\section{Threats}

Destruction of trees for timber production, agricultural land expansions, encroachments, trampling and grazing pressure by livestock are serious threats for future existence of Boutourlini's blue monkeys and other mammals in Komto Protected Forest. Illegal charcoal and commercial timber production are the main threats for wildlife in Komto Protected Forest. Continuous removal of natural forest for timber, charcoal and construction materials will result in a sudden collapse of the forest and local extinction of Boutourlini's blue monkey. Over the last ten years, plantations of seedlings have been carried out in Komto Protected Forest with no evident positive change on the status of the forest. This is because seedlings planted around the edge of the forest have very low survival rate due to trampling by livestock. Community information reveals that the numbers of Boutourlini's blue monkeys in Komto Protected forest are dwindling. Currently, Boutourlini's blue monkeys are restricted to natural and riverine forests. Such restricted preference of narrow ecological niches might lead Boutourlini's blue monkeys to local extinction in Komto Protected Forest. Large trees are selectively harvested for illegal timber production in Komto Protected Forest. This will directly affect Boutourlini's blue monkeys as large trees are preferred for roosting, feeding and predator avoidance. The current status of Komto Protected Forest is not promising for the future survival of 
mammals in general and Boutourlini's blue monkeys in particulars unless special conservation action is designed to conserve Komto Protected Forest.

\section{Conflict of interests}

We have no conflict of interest.

\section{ACKNOWLEDGEMENTS}

We would like to thank the Department of Zoological Sciences, Addis Ababa University for financial support. We are also grateful to East Wollega Forest and Wildlife Enterprise Bureau for providing the map of the area and our filed assistants.

\section{REFERENCES}

Abernethy K (2000). Behavioural ecology data and its relevance for management. In: Conservation of Researches in the African Rain Forest: A Technical Hand Book, $1^{\text {st }}$ edn. Pp.269-321, (White L, Edwards A, eds). Wildlife Conservation Society, New York.

Altmann J (1974). Observational study of behaviour: sampling methods. Behaviour 49:227-267.

Baum JA (2005). Foraging behaviors of Alouatta palliata, Mantled Howling monkeys. Pp.129-140. Nebraska Anthropologist. Paper 1. Available at: http://digitalcommons. unl.edu/nebanthro/1.

Brugiere D, Gautier J, Moungazi A, Gautier-Hion A (2002). Primate diet and biomass in relation to vegetation composition and fruiting phenology in a rainforest in Gabon. Int. J. Primatol. 23:999-1024.

Bunce JA, Isbell LA, Grote MN, Jacobs GH (2011). Color vision variation and foraging behavior in wild Neotropical Titi Monkeys (Callicebus brunneus): Possible mediating roles for spatial memory and reproductive status. Int. J. Primatol. 32:1058-1075.

Butynski TM, Gippoliti S (2008). Cercopithecus mitis ssp. boutourlinii. In: IUCN 2012. IUCN Red List of Threatened Species. Version 2012.1. Available at: www.iucnredlist.org.

Chapman CA and Chapman LJ (2002). Foraging challenges of red Colobus monkeys: Influence of nutrients and secondary compounds. Comp. Biochem. Physiol. 133:861=875.

Chapman CA and Peres CA (2001). Primate conservation in the new millennium: the role of scientists. Evolu. Anthrop. 10:16-33.

Chapman CA, Balcomb SR, Gillespie TR, Skorupa JP and Struhsaker TT (2000). Long-term effects of logging on African primate communities: a 28-year comparison from Kibale National Park, Uganda. Conserv. Biol. 14:207-217.

Chapman CA, Chapman LJ, Cords M, Gathua J M, Gautier-Hion A, Lambert JE, Rode K, Tutin CEG and White LJT (2002). Variation in the diets of Cercopithecus species: Differences within forests, among forests, and across species. In: The Guenons: Diversity and Adaptation of African Monkeys, (Glenn M and Cords M, eds). Kluwer Academic/Plenum Publishers, New York. pp. 325-350

Chapman CA, Lawes MJ and Eeley HAC (2006). What hope for African primate diversity? Afr. J. Ecol. 44:116-133.

Chapman CA, Naughton-Treves L, Lawes MJ, Wasserman MD and Gillespie TR (2007). Population declines of colobus in western Uganda and conservation value of forest fragments. Int. J. Primatol. 28:513-528.

Cordeiro NJ, Patrick DAG, Munisi B and Gupta V (2004). Role of dispersal in the invasion of an exotic tree in an East African submontane forest. J. Trop. Ecol. 20:449-457.

Cords M (1986). Interspecific and intraspecific variation in diet of two forest guenons, Cercopithecus ascanius and C. mitis. J. Ani Ecol. 55:811-827.

Cords M (1987). Mixed-species association of Cercopithecus monkeys in the Kakamega Forest, Kenya. Univ. Calif. Pub. Zool. 117:1-109.

Cords $M$ (2002). Foraging and safety in adult female blue monkeys in the Kakamega forest, Kenya. In: Eat or be Eaten: Predator Sensitive Foraging among Primates, Pp205-221, (Miller, L. E., edr). Cambridge University Press, Cambridge.

Cowlishaw G (1999). Predicting the pattern of decline of African primate diversity: an extinction debt from historical deforestation. Conserv. Biol. 13:1183-1193.

Di Fiore A (2004). Diet and feeding ecology of woolly monkeys in a western Amazonian rain forest. Int. J. Primatol. 25:767-801.

Dietz JM, Peres CA, Pinder L (1997). Foraging ecology and use of space in wild golden lion tamarins (Leontopithecus rosalia). Am. J. Primatol. 41:289-305.

Estes DR (1992). The Behavior guide to African mammals, including hoofed mammals, carnivores, primates. The University of California Press, Los Angeles, California.

Fairgrieve C, Muhumuza G (2003). Feeding ecology and dietary differences between blue monkey (Cercopithecus mitis stuhlmanni Matschie) groups in logged and unlogged forest, Budongo Forest Reserve, Uganda. Afr. J. Ecol. 41:141--149.

Fashing PJ (2001). Activity and ranging patterns of guerezas in the Kakamega Forest: intergroup variation and implications for intragroup feeding competition. Int. J. Primatol. 22:549-577.

Fekadu Gurmessa, Teshome Soromessa, Ensermu Kelbessa (2013). Floristic Composition and Community Analysis of Komto Afromontane Moist Forest, East Wollega Zone, West Ethiopia. Sci. Technol. Arts Res. J. 2:58-69.

IUCN (2010). IUCN Red List of Threatened Species. Version 2010.4. www.iucnredlist.org

Jaffe KE and Isbell LA (2007). The guenons: polyspecific associations in socioecological prospective. In: Primates in Prospective, (Campbell CJ, Fuentes A, Mackinnon KC, Bearder SK and Stumpf RM, eds). Oxford University Press, New York. pp. 277-299.

Kaplin BA and Moermond TC (2000). Foraging ecology of the mountain monkey: Implications for its evolutionary history and use of disturbed forest. Am. J. Primatol. 50:227-246.

Kaplin BA (2001). Ranging behavior of two species of guenons (Cercopithecus Ihoesti and C. mitis doggetti) in the Nyungwe Forest Reserve, Rwanda. Int. J. Primatol. 22:521-548.

Kempe V (2008). Blue monkeys' utilization of five tree species in relation to abundance of each tree species: Diospyros abyssinica, Euclea divinorum, Turraea robusta, Warburgia ugandensisand Ficus lutea. Swedish University of Agricultural Sciences Department of Animal Environment and Health Section of Ethology and Animal Welfare. Student report 212. P 24.

Kerr JT, Deguise I (2004). Habitat loss and the limits to endangered species recovery. Ecol. Lett. 7:1163-1169.

Kingdon J (1971). East African Mammals. An Atlas of Evolution in Africa Volume, Academic Press London New York.

Kingdon J, Gippoliti S, Butynski TM, Lawes MJ, Eeley H, Lehn C, De Jong Y (2008). Cercopithecus mitis. In: IUCN 2012. IUCN Red List of Threatened Species. Available at: www.iucnredlist.com.

Lawes MJ (1990). The distribution of the Samango monkey (Cercopithecus mitis erythrarchus Peters, 1852 and Cercopithecus mitis labiatus Geoffroy, I. 1843) and forest history in southern Africa. Afr. J. Biogeogr. 17:669-680.

Lawes MJ and Chapman CA (2003). Determinants of patch occupancy and the distribution of blue monkey groups: lessons for conservation of guenons. Am. J. Primatol. 60. Special Issue.

Leighton M (1993). Modeling dietary selectivity by Bornean orangutans: evidence for integration of multiple criteria in fruit selection. Int. J. Primatol. 14:257-313.

Linderoth E (2008). Human impact on food choice and diurnal behaviour in blue monkeys (Cercopethecus mitis sthulmanni). Swedish University of Agricultural Sciences. Student report 172. P19.

Maruhashi T (1980). Feeding behaviour and diet of the Japanese Monkey (Macaca fuscata yakui) on Yakushima Island, Japan. Primates. 21:141-160.

Mbora DNM, McPeek MA (2009). Host density and human activities mediate increased parasite prevalence and richness in primates threatened by habitat loss and fragmentation. J. Anim. Ecol. 78:210218 
Mbora DNM, Meikle DB (2004). Forest fragmentation and the distribution, abundance and conservation of the Tana River red colobus (Procolobus rufomitratus). Biol. Conserv. 118: 67-77.

Mosissa G, Yosef M, Afework B (2001). Species richness, abundance and habitat preference of rodents from Komto Protected Forest, western Ethiopia. J. Agric. Biol. Sci. 2:166-175.

Nekaris KAI (2005). Foraging behaviour of the slender loris (Loris lydekkerianus lydekkerianus): implications for theories of primate origins. J. Human Evol. 49:289-300.

Norton-Griffiths M (1978). Counting Animals. Handbook No.1, 2nd edn. African Wildlife Foundation, Nairobi.

Oates JF (1996). Status, Survey and Conservation Action Plan: African Primates. IUCN/SSC Primate Specialist Group, IUCN, Gland.

Rode KD, Chapman CA, Mcdowell LR and Stickler C (2006). Nutritional correlates of population density across habitats and logging Intensities in red tail monkeys (Cercopithecus ascanius). Biotropica 38:625-634.

Rovero F and Struhsaker TT (2007). Vegetative predictors of primate abundance: utility and limitations of a fine-scale analysis. Am. J. Primatol. 69:1-15.

Rudran R (1978). Socioecology of the Blue Monkeys (Cercopithecus mitis stuhlmanni) of the Kibale Forest, Uganda. Smithsonian institution press. City of Washington. P 88.

Smith AD (1959). Adequacy of some important browse species in over wintering mule deer. J. Range Mngt. 12:8-13.

Stuart C (1997). The larger mammals of Africa, Struik publishers, South Africa.

Sutherland WJ (1998). The importance of behavioural studies in conservation biology. Anim. Behav. 56:801-809.

Tashiro Y (2006). Frequent insectivory by two guenons (Cercopithecus Ihoesti and Cercopithecus mitis) in the Kalinzu Forest. Uganda Prim. 47:170-173.

Tesfaye D, Fashing P J, Bekele A, Mekonnen A, Atickem A (2013). Ecological Flexibility in Boutourlini's Blue Monkeys (Cercopithecus mitis boutourlinii) in Jibat Forest, Ethiopia: A Comparison of Habitat Use, Ranging Behavior, and Diet in Intact and Fragmented Forest. Int. J. Primatol. 34:615-640.
Twinomugisha D, Chapman CA, Lawes MJ, Worman C, Danish L (2006). How does the golden monkey of the Virungas cope in a fruit scarce environment? In: Primates of Western Uganda, 45-60, (Newton-Fisher, ed), Springer. Uganda.

Wallace BR, Painter RLE, Taber AB (1998). Primate diversity, habitat preferences and population density in Noel Kempff Mercado National Park. Santa Cruz Department, Bolivia. Am. J. Primatol. 46:197-211.

Wasserman MD, Chapman CA (2003). Determinants of Colobins monkey abundance: the importance of food energy, protein and fibre content. J. Anim. Ecol. 72:650-659.

Wolfheim JH (1982). Primates of the World, Distribution, Abundance and Conservation. New York Zoological Society. University of Washington Press, Seattle and London.

Wong SNP, Sicotte P (2006). Population size and density of Colobus vellerosus at the Boabeng-Fiema monkey Sanctuary and surrounding forest fragments in Ghana. Int. J. Primatol. 68:465-476.

Yalden DW, Largen MJ, Kock D (1977). Catalogue of the mammals of Ethiopia, primates. Monitore Zoologico Italiano. 9:1-52. 